\title{
Effect of essential oils on meat and fat qualities of crossbred young bulls finished in feedlots
}

\author{
Dayane Cristina Rivaroli a,c,*, Ana Guerrero ${ }^{\mathrm{a}, \mathrm{b}}$, Maribel Velandia Valero ${ }^{\mathrm{a}}$, Fernando Zawadzki a \\ Carlos Emanuel Eiras ${ }^{\mathrm{a}}$, Maria del Mar Campo ${ }^{\mathrm{b}}$, Carlos Sañudo ${ }^{\mathrm{b}}$, André Mendes Jorge ${ }^{\mathrm{c}}$, Ivanor Nunes do Prado ${ }^{\mathrm{a}}$ \\ a State University of Maringá, Animal Science Department, CNPq/CAPES Fellowship, 87.020-900 Maringá, Paraná, Brazil \\ ${ }^{\mathrm{b}}$ University of Zaragoza, Animal Production and Food Science Department, Instituto Agroalimentario (IA2) - Universidad de Zaragoza - CITA. C/Miguel Servet 177, 50013 Zaragoza, Spain \\ c São Paulo State University, Animal Production Departament, 18618-970 Botucatu, Sao Paulo, Brazil
}

\section{A R T I C L E I N F O}

\section{Article history:}

Received 17 June 2015

Received in revised form 31 May 2016

Accepted 15 June 2016

Available online 16 June 2016

\section{Keywords:}

Antioxidant effect

Aging

Fatty acid composition

High-concentrate system

Natural additives

\begin{abstract}
A B S T R A C T
Twenty-seven animals ( $1 / 2$ Angus $-1 / 2$ Nellore) were fed for four months with one of the following diets: without addition of essential oils (E0.0), with 3.5 (E3.5) or 7 (E7.0) g/animal/day of an essential oil blend (oregano, garlic, lemon, rosemary, thyme, eucalyptus and sweet orange). Chemical composition, fatty acid profile and meat color were evaluated in Longissimus muscle. In addition, the effects of aging (one, seven and 14 days) on the meat water holding capacity, texture and lipid oxidation were evaluated. Essential oils had no effect on chemical and fatty acid composition, meat color, water holding capacity or texture, but an inclusion of $3.5 \mathrm{~g} / \mathrm{day}$ decreased lipid oxidation. The addition of $7.0 \mathrm{~g} / \mathrm{animal} / \mathrm{day}$ had a pro-oxidant effect on meat during aging and resulted in higher values for lipid oxidation at 14 days of aging. Aging significantly affected thawing losses and texture. A dose of $3.5 \mathrm{~g} / \mathrm{animal} / \mathrm{day}$ could be recommended in feedlot animals, but greater doses could have a pro-oxidant effect.
\end{abstract}

(c) 2016 Elsevier Ltd. All rights reserved.

\section{Introduction}

In Brazil, traditional cattle production systems are extensive and pasture-based (Ferraz \& Felício, 2010) and Zebu breeds (Bos indicus) such as Nellore and European crossbreds (Bos taurus $\times$ Bos indicus) are frequently used (Rotta et al., 2009). In recent years, due to the increased domestic and export beef demand linked to large annual growth in the meat market, the use of more intensive production systems has also increased and performance and meat quality have also improved through this intensification (Prado et al., 2008). Thus, production systems are changing in Brazil and feeds with more energy including a high percentage of concentrate are being utilized, contributing to a shift towards feedlot production systems (Miguel et al., 2014; Rotta et al., 2009).

Over the last decade, the addition of antibiotics in livestock production systems has been common, especially when animals are reared intensively, in order to prevent diseases, metabolic disorders, and to improve feed efficiency (Benchaar, Duynisveld, \& Charmley, 2006; Goodrich et al., 1984). However, due to the emergence of antibiotic resistance and possible risks to human health due to residues in the final products (Russell \& Houlihan, 2003), their use has been forbidden in some regions such as the $\mathrm{EU}$, where research has begun to focus on

\footnotetext{
* Corresponding author.

E-mail address: dayrivaroli@hotmail.com (D.C. Rivaroli).
}

investigating natural alternatives, which are well accepted by consumers (Verbeke et al., 2010). In this sense, plant extracts have an interesting role as a safe food additive (Benchaar et al., 2008; Valero et al., 2014a).

There are several activities of essential oils (Jayasena \& Jo, 2013) as feed additives for livestock because they improve feed efficiency and animal productivity due to their antimicrobial, anti-inflammatory, antioxidant, and digestive modulatory effects on ruminal metabolism (Bakkali, Averbeck, Averbeck, \& Idaomar, 2008; Benchaar et al., 2008). Their antimicrobial activity can decrease ruminal biohydrogenation and consequently increase the deposition of PUFA in meat (Martineau et al., 2008; Scollan et al., 2001).

However, studies on the effects of essential oils on meat quality are still scarce. It has been demonstrated that this effect exists using the essential oils of diverse plants. Oregano and thyme are two species that elevate antioxidant potential due to the presence of phenolic terpenes such as thymol and carvacrol (Bakkali et al., 2008). Each plant has specific active components that dictate the characteristics of its extract. When using a blend, essential oils could have a synergistic effect, influencing their mode of action in animal metabolism and affecting beef quality.

The aim of this study was investigate the effect of different doses of an essential oil blend on meat quality: chemical composition, color, water holding capacity, texture, lipid oxidation and fatty acid 
composition of the Longissimus thoracis muscle of intensively reared young bulls throughout aging (1, 7 and 14 days).

\section{Materials and methods}

\subsection{Locality, animals and diets}

This experiment was approved (no. 185/2012-CEUA) by the ethical committee of São Paulo State University "Julio de Mesquita Filho" (UNESP). The study was conducted at the Rosa \& Pedro Sector of the Experimental Station at Iguatemi Farm, Maringá city, Paraná, Brazil.

Twenty-seven 12 month-old half-brother crossbred young bulls (F1 $-1 / 2$ Angus $-1 / 2$ Nellore) with an average weight of $243.2 \pm 35.3 \mathrm{~kg}$, were randomly assigned to one of three finishing diets ( $n=9$ per treatment). The bulls were allocated in individual pens.

The basal diet was the same for all animals (Table 1 ), and was formulated according to the NRC (2000) recommendations for a $1.50 \mathrm{~kg}$ average daily gain. The three experimental diets were as follows: E0.0 diet without the addition of the essential oil blend or control diet; E3.5 diet with $3.5 \mathrm{~g} / \mathrm{animal} / \mathrm{day}$ of the essential oil blend; and E7.0 diet with $7 \mathrm{~g} / \mathrm{animal} /$ day of the essential oil blend. The oil blend (MixOil ${ }^{\circledR}$ ) was produced by Animal Wellness Products (A.W.P.' ${ }^{\mathrm{TM}}$ ), Oakland, Nebraska, USA, and was added directly into the concentrate. Components of the blend consisted of seven plant extracts: oregano (Origanum vulgare), garlic (Allium sativum), lemon (Citrus limonium), rosemary (Rosmarinus officinalis), thyme (Thymus vulgaris), eucalyptus (Eucalyptus saligna), and sweet orange (Citrus aurantium).

Young bulls were finished on their respective intensive diets (90:10 concentrate:sugarcane bagasse pelletized) for four months until they reached commercial weights ( $440.3 \pm 42.7 \mathrm{~kg}$ ), with $1.64 \pm 0.04 \mathrm{~kg}$ of average daily gain. Afterwards, they were slaughtered at a commercial abattoir situated $20 \mathrm{~km}$ from the feedlot, after a solid fasting period of $12 \mathrm{~h}$ according to the standard cattle finishing routine in Brazil. After slaughter, carcasses were divided medially through the sternum and vertebral column, identified, and chilled at a temperature below $4{ }^{\circ} \mathrm{C}$ for $24 \mathrm{~h}$. After $24 \mathrm{~h}$, Longissimus thoracis (LT) was excised from the left side of the carcass between the sixth and the ninth ribs for subsequent analyses.

\subsection{Nutrient and diet analyses}

The dry matter (DM) content of the ingredients (sugarcane bagasse pellets and concentrate mix) were determined by oven drying at $65^{\circ} \mathrm{C}$ for $72 \mathrm{~h}$ (Table 1 ). The analytical DM content was determined by drying at $135^{\circ} \mathrm{C}$ for $3 \mathrm{~h}$ using method 930.15 . The organic matter content was calculated as the difference between the DM and ash contents, with ash determined through combustion at $550{ }^{\circ} \mathrm{C}$ for $5 \mathrm{~h}$ using method 936 (AOAC, 2005). The neutral detergent fiber and acid detergent fiber contents were determined using methods described by Mertens (2002). Nitrogen content in the samples was determined using method 976.05 (AOAC, 2005). The total digestible nutrient content was obtained using the methodology described by Kearl (1982). Samples were analyzed at the Laboratory of Feed Analyses and Animal Nutrition, at the State University of Maringá.

\subsection{Sampling and meat quality}

Longissimus thoracis (LT) from sixth rib having been previously separated, was weighed and divided into two parts to determine its chemical and fatty acid composition. The rest of the LT was excised from the left side of the carcass between the seventh and the ninth ribs, sliced into steaks (2.5 cm thick), weighed, vacuum-packed (99\% vacuum, with a Sulpack SVC 620 machine, in Polyamide/Polyethylene pouches of $120 \mu \mathrm{m}$ and $1 \mathrm{~cm}^{3} / \mathrm{m}^{2} / 24 \mathrm{~h} 0_{2}$ permeability, $3 \mathrm{~cm}^{3} / \mathrm{m}^{2} / 24 \mathrm{~h} \mathrm{CO}$ permeability measured at $5^{\circ}$ and $75 \%$ relative humidity; water vapor transmission rate (WVTR) was $3 \mathrm{~g} / \mathrm{m}^{2} / 24 \mathrm{~h}$ at $38^{\circ} \mathrm{C}$ and $100 \% \mathrm{RH}$; the vicat softening point of sealing was reached at $97{ }^{\circ} \mathrm{C}$ and it had a dart drop strength of $1300 \mathrm{~g}$ ), and aged for either $24 \mathrm{~h}, 7$ or 14 days before being frozen and stored $\left(-20{ }^{\circ} \mathrm{C}\right)$ for one month for subsequent analyses.

\section{4. $\mathrm{pH}$ measurements}

At $24 \mathrm{~h}$ post-mortem, the LT pH was measured using a Meter Text Model (Tradelab, Contagem MG Brazil) pH-meter and a penetration electrode at the point of the 3rd lumbar vertebra (Young, West, Hart, \& Van Otterdijk, 2004).

\subsection{Chemical composition}

The chemical composition (percentage of water, ash, crude protein, total lipids, and total collagen) was determined by the principle of near infrared transmittance using a Food Scan Lab TM (Foss NIR Systems, Inc., USA) instrument, which operates in transmittance mode from 850 to $1050 \mathrm{~nm}$ at $2 \mathrm{~nm}$ intervals. Samples $(60 \mathrm{~g})$ of minced meat were placed into a glass cup $(90 \times 90 \times 15 \mathrm{~mm})$ and scanned in duplicate. The spectrum of each sample was the average of five scan locations and was recorded as $\log 1 / T$ ( $T=$ transmittance). The duplicate scans of each sample were examined for consistency and then averaged. Total lipids were extracted using the Bligh and Dyer (1959) method with a chloroform/methanol mixture.

\subsection{Meat color}

Meat color was assessed in fresh meat before the steaks were frozen using a Minolta CR-400 spectrophotometer with a $10^{\circ}$ view angle and a D65 illuminant at $24 \mathrm{~h}$, and 7 and 14 days of aging under vacuum package conditions, after blooming for $30 \mathrm{~min}$. Five measurements were taken per sample.

Table 1

Composition ( $\mathrm{g} / \mathrm{kg} \mathrm{DM}$ ) of the diets fed to crossbred young bulls from 243.2 to $440.3 \mathrm{~kg}$ of body weight.

\begin{tabular}{|c|c|c|c|c|c|c|c|c|}
\hline \multirow[t]{2}{*}{ Parameters } & \multicolumn{7}{|c|}{ Ingredients, $\mathrm{g} / \mathrm{kg}$ on DM } & \multirow[t]{2}{*}{ Diets, $\mathrm{g} / \mathrm{kg}$ on DM } \\
\hline & $\mathrm{SCBP}^{\mathrm{a}}$ & Corn grains & Soybean meal & Limestone, $36 \%$ & Yeast & Mineral salt & $\overline{\text { Urea }}$ & \\
\hline Dry matter & 947.0 & 889.3 & 886.0 & 993.0 & 980.0 & 993.0 & 980.0 & 881.3 \\
\hline Organic matter & 980.0 & 991.0 & 937.0 & 107.1 & - & 107.0 & 5.6 & 973.4 \\
\hline Ash & 19.7 & 9.50 & 62.5 & 832.9 & - & 893.0 & 994.4 & 26.60 \\
\hline Crude protein & 18.3 & 89.9 & 490.0 & - & 300.0 & - & 2600 & 125,0 \\
\hline Ether extract & 36.0 & 35.0 & 13.0 & - & - & - & - & 22.0 \\
\hline Neutral detergent fiber & 787.4 & 177.0 & 137.0 & - & - & - & - & 303.0 \\
\hline Acid detergent fiber & 492.0 & 44.0 & 59.7 & - & - & - & - & 148.0 \\
\hline Total digestible nutrients & 430.0 & 900.0 & 840.0 & - & - & - & - & 703.0 \\
\hline Diets & 100 & 819.5 & 65.1 & 4.60 & 0.50 & 4.10 & 6.20 & \\
\hline
\end{tabular}

\footnotetext{
a Sugarcane bagasse pellet.
} 


\subsection{Thawing losses and cooking losses}

To estimate thawing losses, steaks were thawed over the course of $24 \mathrm{~h}$ under refrigeration conditions $\left(4^{\circ} \mathrm{C}\right)$. Afterwards, they were weighed, and thawing losses were calculated as the percentage difference between the fresh and thawed weights.

To assess cooking losses, steaks were weighed and wrapped in aluminum foil. Each sample was cooked in a pre-heated grill at $200{ }^{\circ} \mathrm{C}$ until an internal temperature of $75^{\circ} \mathrm{C}$ was reached, which was monitored using a INCOTERM internal thermocouple. The sample was then moved away from the grill and cooled at ambient temperature. Once the steaks reached $20^{\circ} \mathrm{C}$, each steak was weighed and the cooking losses calculated as the percentage difference in weight before and after cooking.

\subsection{Lipid oxidation}

At each aging time, a small portion from a raw steak was cut and used to assess lipid oxidation (TBARS) using the procedure described by Pfalzgraf, Frigg, and Steinhart (1995). The results were expressed as mg malonaldehyde/kg meat.

\subsection{Texture measurements}

For texture analysis, the previously cooked steaks were analyzed using a Stable Micro Systems TAXT Plus (Texture Technologies Corp., Serial Number 41288, Godalming, Surrey, UK) texture analyzer with a Warner-Bratzler blade, following the principles proposed by Honikel (1998). The meat was cut into rectangular pieces of $1 \mathrm{~cm}^{2}$ cross-section (eight pieces per animal), which were cut perpendicularly to the direction of the muscle fibers.

\subsection{Fatty acid composition}

Fatty acid methyl esters (FAMEs) were prepared by triacylglycerine methylation according to the ISO (1978) method. FAMEs were analyzed in a gas chromatograph (Varian, Palo Alto, CA, USA) equipped with a flame ionization detector and a CP-7420 fused silica capillary column (100 m, $0.25 \mathrm{~mm}$ and $0.39 \mathrm{mmo}$ - diameter, Varian). The column temperature was programmed at $165^{\circ} \mathrm{C}$ for $18 \mathrm{~min}, 180{ }^{\circ} \mathrm{C}\left(30^{\circ} \mathrm{C} \mathrm{min}{ }^{-1}\right)$ for $22 \mathrm{~min}$, and $240{ }^{\circ} \mathrm{C}\left(15^{\circ} \mathrm{C} \mathrm{min}{ }^{-1}\right)$ for $30 \mathrm{~min}$ with 45 -psi pressure. The injector and detector were kept at $220^{\circ} \mathrm{C}$ and $245^{\circ} \mathrm{C}$, respectively. Gas fluxes (White Martins, São Paulo, Brazil) were $1.4 \mathrm{~mL} \mathrm{~min}^{-1}$ for carrier gas $\left(\mathrm{H}_{2}\right) ; 30 \mathrm{~mL} \mathrm{~min}^{-1}$ for make-up gas $\left(\mathrm{N}_{2}\right)$; and $30 \mathrm{~mL} \mathrm{~min}^{-1}$ and $300 \mathrm{~mL} \mathrm{~min}^{-1}$ for $\mathrm{H}_{2}$ and synthetic flame gas, respectively. The sample was injected by using a $1 / 80$ split mode. Fatty acids (FA) were identified by comparing the relative retention time of the FAME peaks of the samples with standard FAMEs 189-19 from the Sigma Company, St Louis, MO, USA by spiking samples with the standard. The peak areas were determined using Star software (Varian, Walnut Creek, CA, USA).

\subsection{Statistical analysis}

The experimental design was completely randomized with three treatments and nine replications. All studied characteristics were tested for normality (Shapiro-Wilk test). Those that showed a normal distribution were analyzed via analysis of variance by using the procedure proc MIXED in the SAS (2004) statistical package (Statistical Analysis System, version 8.1) with the animal identity as a random effect. The experimental diet effect was evaluated (E0.0, E3.5 and E7.0) for all variables and the effect of aging (24 h, 7 and 14 days) on water holding capacity (WHC), lipid oxidation (TBARS) and Warner-Braztler Shear Force (WBSF) variables was evaluated. Differences between group means were assessed by using the Tukey Test $(P<0.05)$.
Table 2

Effect of the inclusion of essential oils in the diet on the final $\mathrm{pH}$ and chemical composition of Longissimus muscle meat from crossbred young bulls.

\begin{tabular}{|c|c|c|c|c|c|}
\hline \multirow[t]{2}{*}{ Items } & \multicolumn{3}{|c|}{ Essential oils } & \multirow[t]{2}{*}{$\mathrm{SEM}^{\mathrm{d}}$} & \multirow[t]{2}{*}{$P$-value } \\
\hline & $\mathrm{E} 0.0^{\mathrm{a}}$ & $\mathrm{E} 3.5^{\mathrm{b}}$ & $\mathrm{E} 7.0^{\mathrm{C}}$ & & \\
\hline $\mathrm{pH} 24$ & 5.67 & 5.42 & 5.76 & 0.07 & 0.13 \\
\hline \multicolumn{6}{|l|}{ Chemical composition } \\
\hline Moisture, \% & 74.02 & 73.86 & 74.01 & 0.20 & 0.94 \\
\hline Ash, \% & 1.52 & 1.65 & 1.40 & 0.04 & 0.12 \\
\hline Crude protein, \% & 22.61 & 22.79 & 22.94 & 0.14 & 0.67 \\
\hline Total lipids, \% & 2.96 & 3.12 & 2.80 & 0.15 & 0.72 \\
\hline Collagen, mg/g of protein & 1.38 & 1.40 & 1.47 & 0.03 & 0.47 \\
\hline
\end{tabular}

a Without essential oils.

b $3.5 \mathrm{~g}$ essential oils/animal/day.

c $7.0 \mathrm{~g}$ essential oils/animal/day.

d SEM: standard error of mean.

\section{Results}

The addition of essential oils to the diets of bulls did not affect $(P>0.05)$ the ultimate $\mathrm{pH}_{(24 \mathrm{~h})}$, which was below 5.8 (Table 2$)$.

The meat chemical composition (moisture, ash, crude protein, and total lipids) was unaffected by the addition of essential oils to the diets $(P>0.05$; Table 2). The results from the control diet (E0.0) were similar to those that were observed with the addition of different levels of essential oils (E3.5 and E7.0). Also, the total collagen content in the LT muscle was similar $(P>0.05)$ in the meat of bulls from the three studied diets (Table 2).

The addition of essential oils did affect $(P<0.05)$ redness $\left(a^{*}\right)$. The redness value was greater for meat from animals fed $3.5 \mathrm{~g} / \mathrm{animal} / \mathrm{day}$ of essential oil blend, compared with meat from animals fed $7.0 \mathrm{~g} / \mathrm{ani}$ mal/day (Table 3).

There was no interaction between diet and aging $(P<0.05)$ in any of the studied variables. Thawing and cooking losses did not differ $(P>0.05)$ among diets (Table 4$)$. However, in the E7.0 group, meat thawing losses increased $(P<0.01)$ with aging.

The addition of essential oils to the diet had effect $(P<0.05)$ on lipid oxidation (Table 4 ) at 1 and 14 days of aging. The diet E7.0 at $24 \mathrm{~h}$ of aging presented intermediate values in oxidation, at the same level of

Table 3

Effect of the inclusion of essential oils in the diet on the meat color of crossbred young bulls.

\begin{tabular}{|c|c|c|c|c|c|}
\hline \multirow[t]{2}{*}{ Item } & \multicolumn{3}{|c|}{ Essential oils } & \multirow[t]{2}{*}{ SEM $^{\mathrm{d}}$} & \multirow[t]{2}{*}{$P$-value } \\
\hline & $\mathrm{E} 0.0^{\mathrm{a}}$ & E3. $5^{\mathrm{b}}$ & E7. $0^{\mathrm{C}}$ & & \\
\hline \multicolumn{6}{|l|}{$\mathrm{L}^{*}$} \\
\hline 1 days & 40.51 & 41.02 & 40.39 & 0.26 & 0.24 \\
\hline 7 days & 38.14 & 40.49 & 37.79 & 0.75 & 0.09 \\
\hline 14 days & 41.80 & 42.25 & 41.31 & 0.43 & 0.30 \\
\hline SEM & 0.72 & 0.69 & 0.65 & & \\
\hline$P$-value & 0.10 & 0.13 & 0.11 & & \\
\hline \multicolumn{6}{|l|}{$a^{*}$} \\
\hline 1 days & 18.26 & 19.20 & 17.92 & 0.44 & 0.02 \\
\hline 7 days & 17.64 & 18.17 & 17.66 & 0.30 & 0.17 \\
\hline 14 days & 18.78 & 19.50 & 18.21 & 0.37 & 0.06 \\
\hline SEM & 0.22 & 0.23 & 0.34 & & \\
\hline$P$-value & 0.10 & 0.06 & 0.82 & & \\
\hline \multicolumn{6}{|l|}{$b^{*}$} \\
\hline 1 days & 7.26 & 7.52 & 6.92 & 0.28 & 0.32 \\
\hline 7 days & 5.67 & 6.30 & 5.67 & 0.22 & 0.38 \\
\hline 14 days & 7.15 & 8.16 & 6.85 & 0.43 & 0.09 \\
\hline SEM & 0.48 & 0.52 & 0.51 & & \\
\hline$P$-value & 0.14 & 0.11 & 0.13 & & \\
\hline
\end{tabular}

a Without essential oils.

b $3.5 \mathrm{~g}$ essential oils/animal/day.

c $7.0 \mathrm{~g}$ essential oils/animal/day.

d SEM: standard error of mean. 
Table 4

Effect of essential oil blend inclusion and aging on water holding capacity, texture and lipid oxidation ( $\mathrm{mg}$ malonaldehyde/ $\mathrm{kg}$ of meat) of meat from crossbred young bulls.

\begin{tabular}{|c|c|c|c|c|c|}
\hline \multirow[t]{2}{*}{ Items } & \multicolumn{3}{|c|}{ Essential oils } & \multirow[t]{2}{*}{ SEM $^{\mathrm{d}}$} & \multirow[t]{2}{*}{$P$-value } \\
\hline & $\mathrm{E} 0.0^{\mathrm{a}}$ & $\mathrm{E} 3.5^{\mathrm{b}}$ & E7. $0^{\mathrm{c}}$ & & \\
\hline \multicolumn{6}{|c|}{ Thawing loss (\%) } \\
\hline 1 day & 7.82 & 8.79 & $7.17 \mathrm{~b}$ & 0.55 & 0.51 \\
\hline 7 days & 10.53 & 9.21 & $10.84 a$ & 0.74 & 0.65 \\
\hline 14 days & 9.39 & 9.86 & $11.20 \mathrm{a}$ & 0.58 & 0.43 \\
\hline SEM & 0.76 & 0.56 & 0.65 & & \\
\hline$P$-value & 0.36 & 0.75 & 0.01 & & \\
\hline \multicolumn{6}{|c|}{ Cooking loss (\%) } \\
\hline 1 day & 28.10 & 24.72 & 27.30 & 0.67 & 0.09 \\
\hline 7 days & 22.70 & 26.28 & 26.05 & 1.06 & 0.32 \\
\hline 14 days & 25.08 & 28.27 & 29.37 & 0.99 & 0.18 \\
\hline SEM & 1.06 & 0.91 & 0.79 & & \\
\hline$P$-value & 0.11 & 0.29 & 0.23 & & \\
\hline \multicolumn{6}{|c|}{ Lipid oxidation, mg MDA/kg muscle } \\
\hline 1 day & $0.10 \mathrm{Ba}$ & $0.07 \mathrm{Aa}$ & $0.08 \mathrm{ABa}$ & 0.01 & 0.04 \\
\hline 7 days & $0.15 a$ & $0.14 \mathrm{a}$ & $0.12 \mathrm{a}$ & 0.01 & 0.24 \\
\hline 14 days & $0.60 \mathrm{ABb}$ & $0.47 \mathrm{Ab}$ & $1.0 \mathrm{Bb}$ & 0.12 & $<0.0001$ \\
\hline SEM & 0.05 & 0.03 & 0.09 & & \\
\hline$P$-value & $<0.0001$ & $<0.0001$ & $<0.0001$ & & \\
\hline \multicolumn{6}{|l|}{ WBSF, N } \\
\hline 1 day & 53.68 & $49.95 a$ & $52.42 a$ & 0.34 & 0.74 \\
\hline 7 days & 43.35 & $35.45 b$ & 40.69b & 0.33 & 0.25 \\
\hline 14 days & 43.58 & $34.00 \mathrm{~b}$ & 43.25ab & 0.31 & 0.06 \\
\hline SEM & 0.38 & 0.29 & 0.30 & & \\
\hline$P$-value & 0.11 & $<0.0001$ & 0.03 & & \\
\hline
\end{tabular}

A, B: different superscript letters represent significant differences within rows, between treatments $(P \leq 0.05)$.

a, b: different superscript letters represent significant differences during aging $(P \leq 0.05)$.

There was no interaction between diet and aging $(P>0.05)$.

a Without essential oils.

b $3.5 \mathrm{~g}$ essential oils/animal/day.

c $7.0 \mathrm{~g}$ essential oils/animal/day.

d SEM: standard error of mean.

significance as found with the other two diets (E0.0 and E3.5), and at 14 days of aging, this diet resulted in higher values than E3.5, but at the same level of significances as the diet E0.0. Meat from animals that were supplemented with $3.5 \mathrm{~g} / \mathrm{animal} / \mathrm{day}$ of essential oils showed the smallest values for lipid oxidation after short and long periods of aging $(P<0.05)$. At seven days of aging, differences in lipid oxidation of meat from the three diets were not significant. However, the addition of $3.5 \mathrm{~g}$ /day of essential oils in the diet seems to be more favorable than $7 \mathrm{~g} /$ day, based on the smaller results for lipid oxidation at 0 and 14 days of aging $(P<0.05)$. Lipid oxidation increased with aging due to all treatments; however, at 14 days those variations were higher $(P<0.05)$.

The addition of essential oils did not modify $(P>0.05)$ meat texture characteristics (Table 4$)$. Also, aging time did not affect $(P>0.05)$ texture values of meat from diets without addition of essential oils, but only in beef from diets with the inclusion of an essential oil blend $(P<0.05)$.

The addition of essential oils to the diet had no effect $(P>0.05)$ on the composition of fatty acids, except for myristoleic acid (Table 5). The percentages of saturated fatty acids (SFA), monounsaturated (MUFA), polyunsaturated (PUFA), $n-3$ fatty acids, $n-6$ fatty acids, PUFA:SFA, and $n-6: n-3$ ratios were not influenced by the addition of essential oils.

\section{Discussion}

\section{1. $p H$}

The $\mathrm{pH}_{(24 \mathrm{~h})}$ observed (below 5.8) was similar to that found by Valero et al. (2014b) in crossbred bulls finished in a feedlot for 55 days and fed with essential oils. The lack of effect in this attribute agrees with the findings of others authors in similar productive conditions (Zawadzki et al., 2011) and implies good handling practice before slaughtering.
Table 5

Effect of essential oils inclusion in the diet on the composition of fatty acids (\% identified fatty acid methyl esters) in the Longissimus muscle of crossbred young bulls.

\begin{tabular}{|c|c|c|c|c|c|}
\hline & \multicolumn{3}{|c|}{ Essential oils } & \multirow[t]{2}{*}{$\mathrm{SEM}^{\mathrm{d}}$} & \multirow[t]{2}{*}{$P$-value } \\
\hline & $\bar{E} 0.0^{\mathrm{a}}$ & E3.5 & $\overline{\mathrm{E} 7.0^{\mathrm{C}}}$ & & \\
\hline $\mathrm{SFA}^{\mathrm{e}}$ & 47.86 & 47.46 & 46.13 & 1.02 & 0.47 \\
\hline$U F A^{f}$ & 52.33 & 53.11 & 54.30 & 1.08 & 0.41 \\
\hline MUFA $^{g}$ & 47.61 & 47.25 & 47.47 & 1.10 & 0.97 \\
\hline PUFA $^{\text {h }}$ & 4.72 & 5.85 & 6.82 & 0.90 & 0.25 \\
\hline$n-3$ & 0.25 & 0.30 & 0.29 & 0.02 & 0.51 \\
\hline$n-6$ & 4.00 & 5.07 & 5.91 & 0.80 & 0.24 \\
\hline PUFA:SFA & 0.10 & 0.12 & 0.15 & 0.02 & 0.18 \\
\hline$n-6 / n-3$ & 15.70 & 16.90 & 19.70 & 2.18 & 0.41 \\
\hline $12: 0$ & 0.03 & 0.03 & 0.03 & 0.00 & 0.78 \\
\hline $14: 0$ & 2.23 & 2.64 & 2.06 & 0.11 & 0.09 \\
\hline $14: 1 n-9$ & $0.41 \mathrm{AB}$ & $0.58 \mathrm{~A}$ & $0.38 \mathrm{~B}$ & 0.03 & 0.02 \\
\hline $15: 0$ & 0.33 & 0.30 & 0.31 & 0.01 & 0.68 \\
\hline $15: 1 n-9$ & 0.66 & 0.75 & 0.84 & 0.05 & 0.42 \\
\hline $16: 0$ & 31.14 & 31.50 & 30.01 & 0.51 & 0.48 \\
\hline $16: 1 n-7$ & 2.29 & 2.62 & 2.14 & 0.10 & 0.18 \\
\hline $17: 0$ & 0.98 & 0.74 & 0.92 & 0.04 & 0.06 \\
\hline $17: 1 n-9$ & 0.70 & 0.65 & 0.72 & 0.05 & 0.86 \\
\hline $18: 0$ & 13.13 & 12.24 & 12.79 & 0.31 & 0.53 \\
\hline $18: 1 n-9$ & 42.73 & 41.64 & 42.43 & 0.59 & 0.76 \\
\hline $18: 1 n-7$ & 0.80 & 0.98 & 0.94 & 0.04 & 0.22 \\
\hline $18: 2 n-6$ & 3.85 & 4.89 & 5.76 & 0.48 & 0.27 \\
\hline $18: 3 n-3$ & 0.10 & 0.12 & 0.10 & 0.00 & 0.59 \\
\hline $18: 2 c 9-t 11$ & 0.04 & 0.05 & 0.04 & 0.00 & 0.67 \\
\hline $20: 3 n-3$ & 0.11 & 0.10 & 0.13 & 0.01 & 0.52 \\
\hline $20: 4 n-6$ & 0.56 & 0.60 & 0.72 & 0.06 & 0.57 \\
\hline $20: 5 n-3$ & 0.04 & 0.06 & 0.04 & 0.00 & 0.35 \\
\hline
\end{tabular}

A, B: different superscript letters represent significant differences within rows, between treatments $(P \leq 0.05)$.

a Without essential oils.

b $3.5 \mathrm{~g}$ essential oils/animal/day.

c $7.0 \mathrm{~g}$ essential oils/animal/day.

d SEM: standard error of mean.

e Saturated fatty acids.

f Unsaturated fatty acids.

g Monounsaturated fatty acids.

h Polyunsaturated fatty acids.

\subsection{Chemical composition}

Differences in composition with the different treatments were predictable because the basal diet was the same in treatments, and subsequently the animals all had the same energy and protein availability. Thus, addition of the essential oil blend did not alter the chemical composition of the meat as observed by Cruz et al. (2014) and Valero et al. (2014b), when cashew and castor extracts were included in the diets of bulls finished in feedlots.

The lack of differences in collagen content of meat from the diets could be expected because it seems that variations in collagen are mainly related to variations in breeds, productive aptitude, precociousness, and age as shown by Christensen et al. (2011). The total collagen content observed in the meat was low $(1.40 \mathrm{mg} / 100 \mathrm{~g})$ in comparison with other studies, where total collagen ranged between 2.02 and $5.33 \mathrm{mg} / \mathrm{g}$ wet tissue (Christensen et al., 2011). In the current study, the animals were young and, in general, young animals present a low collagen content (Lepetit, 2008). Also, according to Aberle et al., (1981), animals fed diets in intensive systems that provide rapid growth can have increased rates of protein turnover, including collagen, resulting in more tender meat since new collagen has higher solubility (Bailey \& Sims, 1977; Burson \& Hunt, 1986).

\subsection{Meat color}

The addition of the essential oil blend influenced $(P<0.05)$ only meat redness $\left(a^{*}\right)$ at the first day of aging. A lack of effect of the addition of essential oils on meat color is in agreement with previous findings (Zawadzki et al., 2011, where the addition of another natural additive 
(propolis) did not yield differences in color in comparison with the control meat.

Redness $\left(a^{*}\right)$ was higher in the meat of animals fed $3.5 \mathrm{~g} /$ animal/day of essential oils, and only significant after 1 day of aging $(P<0.05)$. Globally, an increased a* can be related to low mitochondrial respiratory activity of meat, resulting in increased oxygen at the cut surface, thereby producing a bright red color due to oxymyoglobin (Renerre \& Labas, 1987).

All of the studied color variables showed normal values according to other data for Angus $\times$ Nellore crossbred cattle finished in feedlots, although our animals had lighter and more red meat compared with the data reported by Miguel et al. (2013) $\left(\mathrm{L}^{*}=33.7, \mathrm{a}^{*}=17.3\right.$, and $\mathrm{b}^{*}=$ 4.44). Since dark meat is classed as having an $\mathrm{L}^{*}$ value below 29.7, and light meat has L* > 38.5 (Abularach, Rocha, \& Felício, 1998), as is the case in the current work, the color of the meat of the studied animals could be attractive to consumers that prefer lighter meat.

\subsection{Thawing and cooking losses}

Water holding capacity (WHC) was not influenced by the addition of the essential oil blend to the diet. Our findings could be expected because of the lack of differences among groups in $\mathrm{pH}$, which is one of the parameters that most influences WHC, along with the cut fiber orientation and fat quantity (Huff-Lonergan \& Lonergan, 2005), which were also similar between the muscles of the animals fed the three diets.

Meat from animals fed $7 \mathrm{~g}$ /day of essential oil blend in the diet had thawing loss values that increased with aging. Depending on the active ingredient of each essential oil and its dosage, essential oils can become toxic to the cells and the membrane due to pro-oxidant effects (Bakkali et al., 2008) and thereby increase water losses. Also, water losses increase with aging, especially during the first seven days (Muela, Sañudo, Campo, Medel, \& Beltrán, 2010), which was especially true with the E7.0 treatment. During aging, water loss is expected as a consequence of changes in muscular fibers caused by rigor mortis and modifications of myofibrillar structure (Huff-Lonergan \& Lonergan, 2005). However, the evolution of the changes has not yet been completely defined, as they differ depending on the measurement method and are sometimes correlated with other parameters such as $\mathrm{pH}$ (Insausti et al., 2001).

\subsection{Lipid oxidation (TBARS)}

All treatments had lipid oxidation values that increased between 7 and 14 days of aging. The values found for TBARS are considered low for all times of aging. According to Campo et al., (2006), a TBARS value of around two could be considered the limiting threshold for the acceptability of oxidized beef. In meat from animals fed $7 \mathrm{~g}$ /day of the essential oil blend, the lipid oxidation was higher at 14 days of aging than in the E3.5 treatment and similar to the control (E0.0). These result could be explained because at high doses, essential oils can permeabilize mitochondria and damage them (Bakkali et al., 2008). Thus, by changing the flow of electrons, they could produce more free radicals such as reactive oxygen species (ROS) (Van Houten, Woshner, \& Santos, 2006). ROS, in turn will oxidize lipids, proteins and compounds that are the substrates of the antioxidant activity of essential oils such as phenolic compounds (Bakkali et al., 2008). Therefore, the antioxidants that interact with ROS become prooxidants causing the oxidation of lipids and proteins (Galati \& O'Brien, 2004; Nemeikaitè-Čènienè, Imbrasaitè, Sergedienè, \& Čènas, 2005). At low concentrations of essential oils, this does not occur and antioxidant activity is maintained (Aydın \& Özcan, 2007).

Our findings are globally in agreement with the study of Fasseas, Mountzouris, Tarantilis, Polissiou, and Zervas (2008). They evaluated the antioxidant effects of the inclusion of essential oils from oregano and sage in raw and cooked beef meat at $3 \%$ of the weight of the sample.
These authors reported statistical differences between the control and the meat treated with essential oils and the samples with added oils showed lower oxidation for all days of aging. However, those differences in the raw meat, as in our study, were not maintained during the entire study period (12 days), and the oxidation displayed irregular kinetics where differences were no longer obvious at day 4 of aging but detectable again at 8 days.

Nevertheless, the existence of a significant effect in the first days of aging can be considered as an interesting result for the Brazilian beef cattle industry, because the habit of aging meat is not established in the country and consumers buy and consume beef in the period between 1 and 3 days after slaughter, when antioxidant effects are apparent.

In agreement with a previous review, we found that aging is one of the most important factors in the lipid oxidation process and thus in meat shelf life.

\subsection{Warner-Blaztler Shear Force (WBSF)}

The toughness observed in the current study can be considered low (Shackelford, Wheeler, \& Koohmaraie, 1999) (52.01, 40.49, $39.27 \mathrm{~N}$ at $24 \mathrm{~h}, 7$, and 14 days of aging, respectively) for all treatments after the different aging times. However, after 14 days of aging, meat from animals in the E3.5 treatment group showed a tendency towards more tender meat than meat from the other treatment groups $(P=0.06)$.

A previous report suggested that aging has a significant effect on texture by decreasing the values of shear forces (Monsón, Sañudo, \& Sierra, 2004), but this study was developed with European breeds. As previously reported, meat from zebu cattle (Nellore, Brahman) tends to be less tender than that from Continental and British breeds, which can be attributed to differences in postmortem protein breakdown and calpastatin-calpain activity (O'Connor, Tatum, Wulf, Green, \& Smith, 1997). When the proportion of zebu increases, the calpastatin/calpain ratio also increases; thus, proteolysis due to calpain activity is reduced and tenderness values are lower (Boles \& Swan, 2002; Koohmaraie \& Geesink, 2006).

The lack of significant differences between 24 h, 7, and 14 days of meat aging in the control group of this study, from animals fed diets without the addition of the essential oil blend is similar to the findings of O'Connor et al. (1997), who reported a slower rate of tenderization in crossbred cattle with Bos indicus origin, thereby suggesting that meat from $3 / 8$ Bos indicus needs to be aged for a sufficient period of time (approximately $21 \mathrm{~d}$ ) to compensate for the delayed aging response associated with their higher calpastatin activities. On the other hand, Gomes et al. (2012) and Boles and Swan (2002) obtained shear force results that were similar to ours. Throughout aging, there were significant differences in shear forces between the E3.5 and E7.0 treatments. The incorporation of antioxidants in the meat by adding essential oils to the diet of animals may decrease the oxidation cysteine proteases such as calpain (Harris, Huff-Lonergan, Lonergan, Jones, \& Rankins, 2001). When calpain is oxidized, its activity is affected. Therefore, decreased oxidative processes improve proteolysis and thus the softening of meat (Rowe, Maddock, Lonergan, \& Huff-Lonergan, 2004).

\subsection{Fatty acid percentages}

Fatty acid composition, except for C14:1 n-9, was not influenced by the addition of the essential oil blend to the diet. There are few studies concerning the effect of the addition of essential oils on the fatty acid composition of beef. Nanon, Suksombat, and Yang (2014) suggested that plant extracts, like essential oils, which are composed of terpenes, can influence ruminal biohydrogenation (BH). Stearic acid (C18:0) is the final product of biohydrogenation (Tamminga \& Doreau, 1991) and forms a substantial proportion of the fat in beef (12.72\%), which can be modified with the inclusion of additives in the diet. On the other hand, as we have reported above, a statistical difference was not 
observed between the treatments, probably because the basal diet is the same for all treatments and the diets did not differ in their SFA profiles.

The recommended ratio of PUFA:SFA is higher than 0.45 (HMSO, 1994), and it has an important role in reducing cardiovascular risks (Wood et al., 2008). However, the ratio that was found in the present study was 0.12 , typical of meat from animals from intensive rearing conditions. The addition of essential oils did not influence the PUFA:SFA and $n-6: n-3$ fatty acids ratio. The mean ratio of $n-6 / n-3$ observed was 17.5 . The high ratio of $n-6: n-3$ was due to the high proportion of linoleic acid in the diets from the use of common cereals (e.g. maize, soybean). Enser et al. (1998) observed that meat from pasture-fed animals has a lower $n-6 / n-3$ ratio than meat from animals that consume grain, because pasture has higher levels of $\alpha$-linolenic acid ( $n-3$ fatty acid). The HMSO (1994) recommends consumption of a $4: 1$ ratio of $n-6 / n-3$ or less, since $n-3$ fatty acids and their derivatives help to avoid heart disease and cancer (Calder, 2004).

\section{Conclusions}

The inclusion of $7.0 \mathrm{~g} / \mathrm{animal} / \mathrm{day}$ of a blend of essential oils could have some pro-oxidant effects, since it increased lipid oxidation and water losses and decreased redness. The chemical composition and fatty acid profile were not influenced by the addition of the essential oil blend.

\section{References}

Aberle, E. D., Reeves, E. S., Judge, M. D., Hunsley, R. E., \& Perry, T. W. (1981). Palatability and muscle characteristics of cattle with controlled weight gain: time on high energy diet. Journal Animal Science, 52(4), 757-763.

Abularach, M. L. S., Rocha, C. E., \& Felício, P. E. (1998). Características de qualidade do contrafilé (M. L. dorsi) de touros jovens da raça Nelore. Ciência e Tecnologia de Alimentos, 18(2), 205-210.

AOAC (2005). Association official analytical chemists (18th ed.). Gaitherburg, Maryland, USA: Official methods of analysis.

Aydın, C., \& Özcan, M. M. (2007). Determination of nutritional and physical properties of myrtle (Myrtus communis L.) fruits growing wild in Turkey. Journal of Food Engineering, 79(2), 453-458.

Bailey, A. J., \& Sims, T. J. (1977). Meat tenderness: Distribution of molecular species of collagen in bovine muscle. Journal of the Science of Food and Agriculture, 28(6), 565-570.

Bakkali, F., Averbeck, S., Averbeck, D., \& Idaomar, M. (2008). Biological effects of essential oils-A review. Food and Chemical Toxicology, 46(2), 446-475.

Benchaar, C., Calsamiglia, S., Chaves, A. V., Fraser, G. R., Colombatto, D., McAllister, T. A. et al. (2008). A review of plant-derived essential oils in ruminant nutrition and production. Animal Feed Science and Technology, 145(1-4), 209-228.

Benchaar, C., Duynisveld, J. L., \& Charmley, E. (2006). Effects of monensin and increasing dose levels of a mixture of essential oil compounds on intake, digestion and growth performance of beef cattle. Canadian Journal of Animal Science, 86(1), 91-96.

Bligh, E. G., \& Dyer, W. J. (1959). A rapid method of total lipid extraction and purification. Canadian Journal of Biochemistry and Physiology, 37(8), 911-917.

Boles, J. A., \& Swan, J. E. (2002). Processing and sensory characteristics of cooked roast beef: Effect of breed, age, gender and storage conditions. Meat Science, 62(4), 419-427.

Burson, D. E., \& Hunt, M. C. (1986). Heat-induced changes in the proportion of types I and III collagen in bovine longissimus dorsi. Meat Science, 17(2), 153-160.

Calder, P. C. (2004). n-3 fatty acids and cardiovascular disease: Evidence explained and mechanisms explored. Clinical Science, 107(1), 1-11.

Campo, M. M., Nute, G. R., Hughes, S. I., Enser, M., Wood, J. D., \& Richardson, R. I. (2006). Flavour perception of oxidation in beef. Meat Science, 72(2), 303-311.

Christensen, M., Ertbjerg, P., Failla, S., Sañudo, C., Richardson, R. I., Nute, G. R., et al. (2011). Relationship between collagen characteristics, lipid content and raw and cooked texture of meat from young bulls of fifteen European breeds. Meat Science, 87(1), 61-65.

Cruz, O. T. B., Valero, M. V., Zawadzki, F., Rivaroli, D. C., Prado, R. M., Lima, B. S., et al. (2014). Effect of glycerine and essential oils (Anacardium occidentale and Ricinus communis) on animal performance, feed efficiency and carcass characteristics of crossbred bulls finished in a feedlot system. Italian Journal of Animal Science, 13, 790-797.

Enser, M., Hallett, K. G., Hewett, B., Fursey, G. A. J., Wood, J. D., \& Harrington, G. (1998) Fatty acid content and composition of UK beef and lamb muscle in relation to production system and implications for human nutrition. Meat Science, 49(3), 329-341.

Fasseas, M. K., Mountzouris, K. C., Tarantilis, P. A., Polissiou, M., \& Zervas, G. (2008). Antioxidant activity in meat treated with oregano and sage essential oils. Food Chemistry, 106(3), 1188-1194

Ferraz, J. B. S., \& Felício, P. E. (2010). Production systems - An example from Brazil. Meat Science, 84(2), 238-243.

Galati, G. \& O'Brien, P. J. (2004). Potential toxicity of flavonoids and other dietary phenolics: Significance for their chemopreventive and anticancer properties. Free Radical Biology and Medicine, 37(3), 287-303.
Gomes, R. C., Sainz, R. D., Silva, S. L., César, M. C., Bonin, M. N., \& Leme, P. R. (2012). Feedlot performance, feed efficiency reranking, carcass traits, body composition, energy requirements, meat quality and calpain system activity in Nellore steers with low and high residual feed intake. Livestock Science, 150(1-3), 265-273.

Goodrich, R. D., Garrett, J. E., Gast, D. R., Kirick, M. A., Larson, D. A., \& Meiske, J. C. (1984). Influence of monensin on the performance of cattle. Journal of Animal Science, 58(6), $1484-1498$.

Harris, S. E., Huff-Lonergan, E., Lonergan, S. M., Jones, W. R., \& Rankins, D. (2001). Antioxidant status affects color stability and tenderness of calcium chloride-injected beef. Journal of Animal Science, 79(3), 666-677.

HMSO (1994). England department of health nutritional. Aspects of cardiovascular disease. Reports on Health and Social Subjects, 46, 37-46.

Honikel, K. O. (1998). Reference methods for the assessment of physical characteristics of meat. Meat Science, 49(4), 447-457.

Huff-Lonergan, E. \& Lonergan, S. M. (2005). Mechanisms of water-holding capacity of meat: The role of postmortem biochemical and structural changes. Meat Science, 71(1), 194-204.

Insausti, K., Beriain, M. J., Purroy, A., Alberti, P., Gorraiz, C., \& Alzueta, M. J. (2001). Shelf life of beef from local Spanish cattle breeds stored under modified atmosphere. Meat Science, 57(3), 273-281.

ISO (1978). Animal and vegetable fats and oils - Preparation of methyl esters of fatty acids. Method ISO 5509. Geneva, Switzerland: International Organization for Standardization.

Jayasena, D. D., \& Jo, C. (2013). Essential oils as potential antimicrobial agents in meat and meat products: A review. Trends in Food Science \& Technology, 34(2), 96-108.

Kearl, L. C. (1982). Nutrient requirements of ruminants in developing countries (1st ed.). Utah, UT, USA: International Feedstuffs Institute, Utah Agricultural Experiment Station, Utah State University.

Koohmaraie, M., \& Geesink, G. H. (2006). Contribution of postmortem muscle biochemistry to the delivery of consistent meat quality with particular focus on the calpain system. Meat Science, 74(1), 34-43.

Lepetit, J. (2008). Collagen contribution to meat toughness: Theoretical aspects. Meat Science, 80(4), 960-967.

Martineau, R., Petit, H. V., Benchaar, C., Lapierre, H., Ouellet, D. R., Pellerin, D., et al. (2008). Effects of lasalocid or monensin on in situ biohydrogenation of flaxseed and sunflower seed unsaturated fatty acids. Canadian Journal of Animal Science, 88(2), 335-339.

Mertens, D. R. (2002). Gravimetric determination of amylase-treated neutral detergent fiber in feeds with refluxing in beakers or crucibles: Collaborative study. Journal of AOAC International, 85(6), 1217-1240.

Miguel, G. Z., Faria, M. H., Roça, R. O., Santos, C. T., Suman, S. P., Faitarone, A. B. G., et al. (2013). Immunocastration improves carcass traits and beef color attributes in Nellore and Nellore $\times$ Aberdeen Angus crossbred animals finished in feedlot. Meat Science.

Miguel, G. Z., Faria, M. H., Roça, R. O., Santos, C. T., Suman, S. P., Faitarone, A. B. G., et al. (2014). Immunocastration improves carcass traits and beef color attributes in Nellore and Nellore $\times$ Aberdeen Angus crossbred animals finished in feedlot. Meat Science, 96(2), 884-891.

Monsón, F., Sañudo, C., \& Sierra, I. (2004). Influence of cattle breed and ageing time on textural meat quality. Meat Science, 68(4), 595-602.

Muela, E., Sañudo, C., Campo, M. M., Medel, I., \& Beltrán, J. A. (2010). Effect of freezing method and frozen storage duration on instrumental quality of lamb throughout display. Meat Science, 84(4), 662-669.

Nanon, A., Suksombat, W., \& Yang, W. Z. (2014). Effects of essential oils supplementation on in vitro and in situ feed digestion in beef cattle. Animal Feed Science and Technology (196), 50-59.

Nemeikaitė-Čènienė, A., Imbrasaitė, A., Sergedienė, E., \& Čènas, N. (2005). Quantitative structure-activity relationships in prooxidant cytotoxicity of polyphenols: Role of potential of phenoxyl radical/phenol redox couple. Archives of Biochemistry and Biophysics, 441(2), 182-190.

NRC (2000). Nutrient requirements of beef cattle (7th rev. ed.). Washington, DC, USA: Natl. Acad. Press.

O'Connor, S. F., Tatum, J. D., Wulf, D. M., Green, R. D., \& Smith, G. C. (1997). Genetic effects on beef tenderness in Bos indicus composite and Bos taurus cattle. Journal of Animal Science, 75(7), 1822-1830.

Pfalzgraf, A., Frigg, M., \& Steinhart, H. (1995). Alpha tocopherol contents and lipid oxidation in pork muscle and adipose tissue during storage. Journal of Agricultural and Food Chemistry, 43(5), 1339-1342.

Prado, I. N., Ito, R. H., Prado, J. M., Prado, I. M., Rotta, P. P., Matsushita, M., et al. (2008). The influence of dietary soyabean and linseed on the chemical composition and fatty acid profile of the Longissimus muscle of feedlot-finished bulls. Journal of Animal and Feed Sciences, 17, 307-317.

Renerre, M., \& Labas, R. (1987). Biochemical factors influencing metmyoglobin formation in beef muscles. Meat Science, 19(2), 151-165.

Rotta, P. P., Prado, R. M., Prado, I. N., Valero, M. V., Visentainer, J. V., \& Silva, R. R. (2009). The effects of genetic groups, nutrition, finishing systems and gender of Brazilian cattle on carcass characteristics and beef composition and appearance: A review. AsianAustralasian Journal of Animal Sciences, 22(12), 1718-1734

Rowe, L. J., Maddock, K. R., Lonergan, S. M., \& Huff-Lonergan, E. (2004). Oxidative environments decrease tenderization of beef steaks through inactivation of $\mu$-calpain. Journal of Animal Science, 82(11), 3254-3266.

Russell, J. B., \& Houlihan, A. J. (2003). Ionophore resistance of ruminal bacteria and its potential impact on human health. FEMS Microbiology Reviews, 27(1), 65-74.

SAS (2004). SAS/STAT User guide, Version 9.1.2. Cary, NC, USA: SAS Institute Inc.

Scollan, N. D., Dhanoa, M. S., Choi, N. J., Maeng, W. J., Enser, M., \& Wood, J. D. (2001). Biohydrogenation and digestion of long chain fatty acids in steers fed on different sources of lipid. The Journal of Agricultural Science, 136(03), 345-355. 
Shackelford, S. D., Wheeler, T. L., \& Koohmaraie, M. (1999). Evaluation of slice shear force as an objective method of assessing beef longissimus tenderness. Journal of Animal Science, 77(10), 2693-2699.

Tamminga, S., \& Doreau, M. (1991). Lipids and rumen digestion. In J. P. Jouany (Ed.), Rumen microbial metabolism and ruminant digestion (pp. 151-164). Paris, FR: Institut National de la Recherche Agronomique.

Valero, M. V., Prado, R. M., Zawadzki, F., Eiras, C. E., Madrona, G. S., \& Prado, I. N. (2014a). Propolis and essential oils additives in the diets improved animal performance and feed efficiency of bulls finished in feedlot. Acta Scientiarum. Animal Sciences, 36(4), 419-426.

Valero, M. V., Torrecilhas, J. A., Zawadzki, F., Bonafé, E. G., Madrona, G. S., Prado, R. M., et al. (2014b). Propolis or cashew and castor oils effects on composition of Longissimus muscle of crossbred bulls finished in feedlot. Chilean Journal of Agricultural and Research, 74(4), 445-451.

Van Houten, B., Woshner, V., \& Santos, J. H. (2006). Role of mitochondrial DNA in toxic responses to oxidative stress. DNA Repair, 5(2), 145-152.
Verbeke, W., Van Wezemael, L., Barcellos, M. D., Kügler, J. O., Hocquette, J. F., Ueland, Ø. et al. (2010). European beef consumers' interest in a beef eating-quality guarantee. Insights from a qualitative study in four EU countries. Appetite, 54(2), 289-296.

Wood, J. D., Enser, M., Fisher, A. V., Nute, G. R., Sheard, P. R., Richardson, R. I., et al. (2008) Fat deposition, fatty acid composition and meat quality: A review. Meat Science, 78(4), 343-358.

Young, O. A., West, J., Hart, A., \& Van Otterdijk, F. F. H. (2004). A method for early determination of meat ultimate pH. Meat Science, 66(2), 493-498.

Zawadzki, F., Prado, I. N., Marques, J. A., Zeoula, L. M., Rotta, P. P., Sestari, B. B., et al. (2011). Sodium monensin or propolis extract in the diets of feedlot-finished bulls: Effects on animal performance and carcass characteristics. Journal of Animal and Feed Sciences, 20(1), 16-25. 